\title{
Effect of Melatonin on Some Oxidative Stress Parameters in Streptozotocin-Induced Diabetes in Rats
}

\author{
${ }^{\$}$ Manal AlBatch, ${ }^{\$}$ Fathy M. ElFasakhany, " Abdel Razek Sheta, \\ \$Safwat Kasim \\ ${ }^{\$}$ Department of Medical Biochemistry, "Department of Anatomy, \\ Faculty of Medicine, Tanta University, Egypt
}

\begin{abstract}
Diabetes mellitus has been shown to be a state of increased free radicals and disturbance in antioxidant defense system. The aim of the present study was to investigate the protective effect of melatonin on some oxidative stress parameters in both blood and tissues, liver and pancreas, in streptozotocin (STZ)-induced diabetes in rats. Three groups of rats were used, control group, diabetic group and a group of diabetic rats treated with melatonin. Malondialdehyde (MDA) level was used as a marker of lipid peroxidation, advanced oxidation protein product (AOPP) level as a marker for protein damage and activity of antioxidant enzymes; glutathione peroxidase (GPx) and paraoxonase (PON) were, also, assessed. Liver and pancreatic malondialdehyde and plasma AOPP levels were significantly reduced but serum PON1 and pancreatic GPx activities were significantly increased by melatonin treatment. Liver GPx activities showed no significant differences among all studied groups. Microscopic examination of liver showed improvement of the morphological and histopathological changes induced by diabetes. These data suggested that melatonin treatment has a partial therapeutic effect in diabetes by reduction of oxidative stress and by stimulation of various antioxidant enzymes.
\end{abstract}

Key words: STZ, melatonin, oxidative stress, MDA, Diabetes mellitus.

\section{INTRODUCTION}

Oxidative stress has been implicated in the pathogenesis and progression of many degenerative diseases including diabetes. Free radicals reactions may play an important role in diabetic complications $^{(\mathbf{1})}$. Free radicals may cause oxidative damage of cellular membranes and changes in the structural and functional integrity of subcellular organelles and may produce effects that result in various complications in diabetic disease ${ }^{(2)}$.
Therefore, assessment of oxidative stress in diabetic patients may be important for the prediction and prevention of diabetic complications $^{(3)}$.

One of the oxidative stress parameters is malondialdehyde (MDA), which is one of the end products of lipid peroxidation induced by reactive oxygen species (ROS). Lipid peroxidation is a wellestablished mechanism of cellular injury $^{(4)}$. Damage to proteins and DNA may often be more important than damage to lipids in oxidative 
stress situations in vivo. ${ }^{(5)}$ The use of oxidative modification products of proteins as a marker may have some advantages in comparison with other markers, because of their relatively early formation, greater stability and reliability and, also, their longer life$\operatorname{span}^{(6)}$.

Oxidative damage to proteins is reflected by increased levels of AOPP which therefore serve as a novel marker of oxidative stress ${ }^{(7)}$.

To protect cells against damage caused by ROS, organisms have developed several defense mechanisms which include antioxidant enzymes and different small antioxidant molecules, such as vitamins $\mathrm{C}, \mathrm{E}$ and flavonoids. The antioxidant enzymes represent the first line of defense against toxic free radicals by metabolizing ROS into non-toxic products $^{(\mathbf{8})}$. These antioxidant defense systems are disturbed in diabetes mellitus ${ }^{(\mathbf{9})}$.

Furthermore, there is a relationship between diabetes and impairment of lipid metabolism; high density lipoprotein (HDL) protects low density lipoprotein (LDL) oxidation, and this protection is impaired in diabetic cases, the antioxidant activity of HDL depends on its associated antioxidant enzymes mainly paraoxonase (PON) ${ }^{\mathbf{( 1 0 )}}$.

Paraoxonase (PON) is a calcium dependent antioxidant enzyme that circulates on HDL and contains apoA1 and clusterin. The paraoxonase gene family contains three members, and the PON1 gene product is serum PON, which is expressed mainly in the liver and normally hydrolyzes organophosphates $^{(\mathbf{1 1})}$.
PON has been shown to protect LDL from oxidative modifications and lipid peroxidation by hydrolyzing biologically active oxidized phospholipids. Moreover, it was reported that less efficient protection mechanisms of PON may be one feature of the greater susceptibility to oxidation in diabetes ${ }^{(8)}$.

There is evidence that antioxidant treatment is beneficial in diabetic rats, and in diseases associated with oxidative stress $^{(\mathbf{1 2})}$.

Melatonin (N-acetyl-5methoxytryptamine), a secretory product of the pineal gland, is a potent scavenger of hydroxyl and peroxyl radical and regulates activity of antioxidant enzymes ${ }^{(\mathbf{1})}$. Melatonin ameliorated carbon tetrachlorideinduced hepatic fibrogenesis in rats via inhibition of oxidative stress and proinflammatory cytokines production $^{(\mathbf{1 3 )}}$. Also, melatonin prevents the tissue damage and fibrosis associated with thioacetamide -induced liver cirrhosis in rats ${ }^{(\mathbf{1 4})}$.

So, the aim of the present study was to investigate the protective effect of melatonin on oxidative stress parameters in both blood and tissues (liver and pancreatic tissues) in STZinduced diabetes in rats and to describe the hepatic microscopic changes and the structural-functional relationships of experimentally diabetic rats and the possibility of tissue protection by melatonin.

\section{MATERIALS \& METHODS}

\section{Animals:}

The present study was carried out on 130 male albino rats of Wistar strain with body weight ranging from 
90 to $140 \mathrm{~g}$. Animals were fed on standard rat chaw and allowed free access to water. They were kept under constant environmental conditions ( 25 $\dot{\mathrm{C}}$ and $12 \mathrm{~h}$ dark/light cycle). All animals were weighed at the beginning and at the end of the study. The rats were classified into three groups:

Group I (control group) included 10 rats, received intraperitoneal injection of a single dose of $0.1 \mathrm{M}$ citrate buffer $\mathrm{pH}$ : 4.0 .

Group II (diabetic group): That group included 60 diabetic rats. Diabetes was induced by intraperitoneal injection of a single dose $(60 \mathrm{mg} / \mathrm{kg})$ of STZ. Group III (diabetic rats treated with melatonin): That group included 60 diabetic rats treated with melatonin. Melatonin was injected intraperitoneally three days prior to induction of diabetes in a dose of $(200 \mu \mathrm{g} / \mathrm{kg} /$ day $)$ daily for 4 weeks. By the end of the study only 20 rats of the diabetic and 20 melatonin injected diabetic rats in addition to 10 control rats remained on which statistical analysis were performed.

Blood samples were collected from tail vein in $\mathrm{K}_{3}$ EDTA (tripotassium ethylene diaminetetraacetic acid) coated tubes to determine basal fasting plasma glucose level. At the end of the experiment, the animals were sacrificed and blood samples were collected for determination of final plasma glucose level and PON1 activity.

Chemicals:

Most chemicals including STZ and melatonin were purchased from Sigma chemical Co.

Methods:

Induction of experimental diabetes:
STZ was used to induce damage to pancreatic beta cells and produce type I diabetes. ${ }^{(1)}$ A single dose of STZ $(60 \mathrm{mg} / \mathrm{kg})$, dissolved in citrate buffer $0.1 \mathrm{M} \quad \mathrm{pH} \quad 4.0$ and injected intraperitoneally. Control group received intraperitoneal injection of a single dose of $0.1 \mathrm{M}$ citrate buffer $\mathrm{pH}$ 4.0. Rats with fasting blood glucose levels of $250 \mathrm{mg} / \mathrm{dl}$ or above were considered diabetic.

\section{Melatonin Injection:}

Three days prior to induction of diabetes, a solution of melatonin was injected $\quad(200 \quad \mu \mathrm{g} / \mathrm{kg} / \mathrm{day}$ intraperitoneally dissolved in $0.5 \mathrm{ml}$ of normal saline containing $0.1 \mathrm{ml} 1 \%$ ethanol). These injections were repeated daily until the end of the study (4 weeks). The dose of melatonin was chosen on the basis of a previous study ${ }^{(15)}$.

Fasting plasma glucose level was determined by enzymatic colorimetric glucose oxidase method using a commercial kit (Elitech Diagnostics Company, France) according to the manufacturer instructions.

Plasma AOPP level: was determined according to the method of Witko Sarsat et al., $1996^{(\mathbf{1 6})}$.

Plasma PON1 enzyme activity: PON1 activity was measured by adding plasma to Tris buffer (100 $\mathrm{mmol} / \mathrm{L}, \mathrm{pH} 8.0$ ) containing $2 \mathrm{mmol} / \mathrm{L}$ $\mathrm{CaCl}_{2}$ and $1 \mathrm{mmol} / \mathrm{L}$ paraoxon $(\mathrm{O}, \mathrm{O}-$ diethyl-O-nitrophenylphosphate

(Sigma chemical Co.). The rate of generation of P-nitrophenol was determined at $405 \mathrm{~nm}, 25^{\circ} \mathrm{C}$ with the use of continuously recording spectrophotometer as described previously ${ }^{(17)}$.

Liver and pancreatic tissue MDA

level: MDA levels were measured 
according to a method described elsewhere $^{(4)}$. That method depends on the fact that MDA reacts with thiobarbituric acid (TBA) producing thiobarbituric acid reactive substance (TBARS), a pink chromogen, which can be measured spectrophotometrically at $532 \mathrm{~nm}$. MDA expressed as $\mathrm{nmol} / \mathrm{g}$ tissue and was calculated using $1.65 \times 10^{5} \mathrm{M}^{-1}$ $\mathrm{cm}^{-1}$ as molar absorption coefficient.

Liver and pancreatic tissue glutathione GPx enzyme Activity: GPx catalyzes the oxidation of reduced glutathione (GSH) in the presence of hydrogen peroxide. In the presence of glutathione reductase (GR) and NADPH the oxidized glutathione (GSSG) is immediately converted to the reduced form with a concomitant oxidation of NADPH to NADP ${ }^{+}$. The decrease in absorbance at $340 \mathrm{~nm}$ was measured. The enzyme activity was calculated using a molar extinction coefficient for NADPH of $6.220 \mathrm{M}^{-1} \mathrm{~cm}^{-1}$ and normalized to protein concentration $^{(\mathbf{1 8 )}}$.

Determination of Protein content in tissue homogenate: Protein content in tissue homogenate was determined by the lowry method (Lowry et al ${ }^{(19)}$ ). Microscopic examination:

At the end of each experiment, the animals were sacrificed and small parts from the liver were immediately fixed in $10 \%$ formaldehyde, dehydrated in ascending grades of alcohol, cleared in xylol and impregnated in soft paraffin for 2 hours at $56{ }^{\circ} \mathrm{C}$ then embedded in hard paraffin. Sections of 6 microns thickness were cut by the microtome and stained with hematoxylin and eosin (H\&E) technique ${ }^{(\mathbf{2 0})}$.

\section{Statistical analyses:}

Results were expressed as the mean \pm SD. Means of different groups were compared using a one-way analysis of variance (ANOVA) followed by Tukey's post hoc test. Paired t-test was performed for evaluation of significant differences between two groups at the start and at the end of experiments. $\mathrm{P}<0.05$ was accepted as significant. Correlation between variables was evaluated using Pearson's correlation coefficient using SPSS version 8 .

\section{RESULTS}

The results were demonstrated through the following tables and figures:

Table (1) shows comparison between the studied groups as regards initial and final body weight in which, there was no statistically significant difference between values of initial body weight (g) among the studied groups, but there were statistically significant differences between values of final body weight ( $\mathrm{g}$ ) among all studied groups ( $\mathrm{F}$ value was 26.39, $\mathrm{P}<0.001)$. By using the multiple comparisons test (Tukey's test), final body weight in group II and group III was significantly lower than in group I $(\mathrm{P}<0.001)$, and there was no significant difference between group II and group III $(\mathrm{P}>0.05)$.

As regards Initial and final plasma glucose levels: Table (1) shows no statistically significant differences between values of initial fasting plasma glucose level (mg/dl) among all studied groups but there were statistically significant differences between values of final 
fasting plasma glucose level among all studied groups ( $\mathrm{F}$ value was 154.980, $\mathrm{P}<0.001)$. By using the Tukey's test, final fasting plasma glucose level was significantly higher in group II and group III $(\mathrm{P}<0.001)$ than group I, but there was no statistically significant difference between group II and group III $(\mathrm{P}>0.05)$.

Table (2) shows comparison between the studied groups as regards initial and final body weight. By using paired t-test, there was a statistically significant differences between values of initial body weight and final body weight (g.) in group I $(\mathrm{P}<0.001)$ and in group II $(\mathrm{P}<0.001)$ but there was no statistically significant difference in group III $(\mathrm{P}>0.05)$.

Table (3) shows comparison between the studied groups as regards initial and final fasting plasma glucose levels. By using paired t-test, there were statistically significant differences between values of initial and final fasting plasma glucose level in group II $(\mathrm{P}<0.001)$ and in group III $(\mathrm{P}<0.001)$ but there was no statistically significant difference in group I $(\mathrm{P}>0.05)$. So, melatonin treatment did not induce a significant change in plasma glucose level in diabetic rats and did not inhibit the development of diabetes induced by STZ.

As regards Plasma advanced oxidation protein product (AOPP): Table (1) shows that there were statistically significant differences in AOPP level ( $\mu \mathrm{mol} / 1)$ among all studied groups (F value was 6.558, $\mathrm{P}<0.05)$. By using Tukey's test, AOPP level in group II was significantly higher than group I and group III $(\mathrm{P}<0.05)$ with no statistically significant difference between group I and group III $(\mathrm{P}>0.05)$.

Regarding plasma PON1 activity: Table (1) shows that there were statistically significant differences between values of plasma PON1 activity among all studied groups (F value was 41.106, $\mathrm{P}<0.001)$. By using Tukey's test, plasma PON1 activity (nmol/min/ml) in group II was significantly lower than group I $(\mathrm{P}<0.001)$, and group III $(\mathrm{P}<0.001)$ with no statistically significant difference between group I and group III $(\mathrm{P}>0.05)$.

Concerning liver and pancreatic MDA, there were statistically significant differences between values of MDA (nmol/g tissue) levels in liver and pancreatic homogenates among all studied groups $(\mathrm{P}<0.001)$. By using the Tukey's test, MDA levels in liver and pancreatic homogenates in group II were significantly higher than in group I and group III $(\mathrm{P}<0.001)$ with no statistically significant difference between group I and group III $(\mathrm{P}>0.05)$. That finding means that MDA level of diabetic rats treated with melatonin did not differ from those control rats (table 1).

Finally regarding liver and pancreatic glutathione peroxidase (GPx) activity: there were statistically significant differences between values of GPx activity (nmol oxidized $\mathrm{NADP} / \mathrm{min} / \mathrm{mg}$ protein) in pancreatic homogenate among all studied groups ( $\mathrm{F}$ value was $12.500, \mathrm{P}<0.001$ ). By using Tukey's test, GPx activity in pancreatic homogenate in group II was significantly lower than group I $(\mathrm{P}<0.05)$ and group III $(\mathrm{P}<0.001)$ with 
no statistically significant difference between group I and group III $(\mathrm{P}>0.05$, table. 7). On the other hand, there were no statistically significant differences between values of GPx activity in liver homogenate among all groups ( $\mathrm{F}$ value was $0.174, \mathrm{P}>0.05$, table (1)

Table (4) shows correlation matrix between the studied variables in the diseased diabetic groups $(n=40)$ in which fasting final plasma glucose level was significantly positively correlated with both liver and pancreatic MDA levels ( $\mathrm{r}=0.47,0.42$ respectively with $\mathrm{P}<0.05)$, but significantly negatively correlated with pancreatic GPx activity ( $\mathrm{r}=-$ 0.583, $\mathrm{P}<0.001)$. Also, a significant positive correlation was found on onehand between liver MDA levels and pancreatic MDA levels $(\mathrm{r}=0.483, \mathrm{P}<$ 0.05 ) and on the other-hand between liver MDA levels and plasma AOPP levels $(\mathrm{r}=0.488, \mathrm{P}<0.001)$. Finally a significant positive correlation was found between pancreatic MDA levels and plasma AOPP levels $(\mathrm{r}=0.365, \mathrm{P}<$ $0.05)$.

Histopathological results of the liver:

Fig.1A shows liver sections of the control group showing the hepatic lobules, with central hepatic veins forming their central axes. The hepatocytes are arranged radialy from the central vein inside the hepatic lobule. They form flat anastomosing plates usually one or two cells thick separated by thin walled blood sinusoids. The hepatocytes appeared polyhedral in shape with large rounded vesicular nuclei containing dispersed chromatin and one or more prominent nucleoli. Fig. 1B shows liver sections of diabetic rats with marked hypertrophy of the hepatic cells. The cytoplasm appeared degenerated and vacuolated and the nuclei were small and darkly stained. Heavy cellular infiltration was noticed in the portal area. Small areas of focal necrosis and degeneration were, also, noticed surrounded by vacuolated and hypertrophied hepatocytes (Fig. 1C). In diabetic rats treated with melatonin, the normal liver architecture was nearly preserved. In contrast to the second group, the liver cells appeared nearly normal with normal nuclei and absence of the cytoplasmic vacuoles. The inflammation was markedly decreased however; few inflammatory cells mainly around the blood vessels were observed (Fig. 1D). 
Table 1:Comparison between the studied groups as regards weight and all studied biochemical parameters $(n=50)$

\begin{tabular}{|c|c|c|c|c|c|}
\hline & $\begin{array}{c}\text { Group } \\
\text { I(n=10) } \\
\text { Mean } \pm \text { SD }\end{array}$ & $\begin{array}{c}\text { Group II } \\
(n=20) \\
\text { Mean } \pm \text { SD }\end{array}$ & $\begin{array}{c}\text { Group } \\
\text { III }(\mathbf{n}=\mathbf{2 0}) \\
\text { Mean } \pm \text { SD }\end{array}$ & $\mathbf{F}$ & P-value \\
\hline Initial body weight (g.) & $115.0 \pm 13.94$ & $115.25 \pm 15.86$ & $114.5 \pm 13.47$ & 0.014 & 0.99 \\
\hline Final body weight (g.) & $152.0 \pm 18.14$ & $100.0 \pm 21.28$ & $109.4 \pm 16.49$ & 26.38 & $<0.001 *$ \\
\hline Group I vs. group II & \multicolumn{5}{|c|}{$\mathbf{P}<0.001 *$} \\
\hline Group I \& Group III & \multicolumn{5}{|c|}{$\mathbf{P}<0.001^{*}$} \\
\hline Group II \& Group III & \multicolumn{5}{|c|}{0.266} \\
\hline $\begin{array}{l}\text { Initial fasting plasma } \\
\text { glucose level (mg/dl) }\end{array}$ & $99.00 \pm 12.86$ & $102.55 \pm 14.11$ & $100.65 \pm 13.912$ & 0.237 & 0.79 \\
\hline $\begin{array}{l}\text { Final fasting plasma } \\
\text { glucose level (mg/dl) }\end{array}$ & $101.00 \pm 11.74$ & $353.00 \pm 42.53$ & $328.90 \pm 35.82$ & 154.98 & $<0.001^{*}$ \\
\hline Group I vs. group II & \multicolumn{5}{|c|}{$\mathbf{P}<0.001 *$} \\
\hline Group I \& Group III & \multicolumn{5}{|c|}{$\mathbf{P}<0.001^{*}$} \\
\hline Group II \& Group III & \multicolumn{5}{|c|}{ P 0.094} \\
\hline $\begin{array}{l}\text { Plasma AOPP level } \\
(\mu \mathrm{mol} / \mathrm{l})\end{array}$ & $\begin{array}{l}24.422 \pm \\
4.238 \\
\end{array}$ & $30.252 \pm 7.223$ & $25.261 \pm 4.375$ & 6.558 & $0.003 *$ \\
\hline Group I vs. group II & \multicolumn{5}{|c|}{ P $0.029^{*}$} \\
\hline Group I \& Group III & \multicolumn{5}{|c|}{ P 0.997} \\
\hline Group II \& Group III & \multicolumn{5}{|c|}{ P $0.005^{*}$} \\
\hline $\begin{array}{l}\text { Serum PON } 1 \text { activity } \\
(\mathrm{nmol} / \mathrm{min} / \mathrm{ml})\end{array}$ & $\begin{array}{l}15.064 \pm \\
2.505 \\
\end{array}$ & $6.924 \pm 2.519$ & $13.636 \pm 3.122$ & 41.106 & $<0.001^{*}$ \\
\hline Group I vs. group II & \multicolumn{5}{|c|}{$\mathbf{P}<0.001^{*}$} \\
\hline Group I \& Group III & \multicolumn{5}{|c|}{ P 0.387} \\
\hline Group II \& Group III & \multicolumn{5}{|c|}{ P $0.001 *$} \\
\hline $\begin{array}{l}\text { Liver MDA level (nmol/g. } \\
\text { tissue) }\end{array}$ & $23.549 \pm 3.003$ & $31.554 \pm 5.456$ & $24.305 \pm 3.829$ & 20.340 & $<0.001^{*}$ \\
\hline Group I vs. group II & \multicolumn{5}{|c|}{$\mathbf{P}<0.001^{*}$} \\
\hline Group I \& Group III & \multicolumn{5}{|c|}{ P 0.989} \\
\hline Group II \& Group III & \multicolumn{5}{|c|}{$\mathbf{P}<0.001^{*}$} \\
\hline $\begin{array}{l}\text { Pancreatic MDA level } \\
\text { (nmol/g. tissue) }\end{array}$ & $16.227 \pm 2.656$ & $31.680 \pm 4.914$ & $19.926 \pm 5.085$ & 49.038 & $<0.001^{*}$ \\
\hline Group I vs. group II & \multicolumn{5}{|c|}{$\mathbf{P}<0.001^{*}$} \\
\hline Group I \& Group III & \multicolumn{5}{|c|}{ P 0.110} \\
\hline Group II \& Group III & \multicolumn{5}{|c|}{$\mathbf{P}<0.001^{*}$} \\
\hline $\begin{array}{l}\text { Liver GPx activity(nmol/ } \\
\text { oxidized NADPH/min/mg } \\
\text { protein }\end{array}$ & $7.900 \pm 1.106$ & $7.763 \pm 1.106$ & $7.788 \pm 1.351$ & 0.174 & 0.841 \\
\hline $\begin{array}{l}\text { Pancreatic GPx } \\
\text { activity }(\mathrm{nmol} / \text { oxidized } \\
\mathrm{NADPH} / \mathrm{min} / \mathrm{mg} \text { protein }\end{array}$ & $4.956 \pm 1.031$ & $2.648 \pm 1.166$ & $4.582 \pm 1.411$ & 12.500 & $<0.001^{*}$ \\
\hline Group I vs. group II & \multicolumn{5}{|c|}{ P $0.015^{*}$} \\
\hline Group I \& Group III & \multicolumn{5}{|c|}{ P 0.526} \\
\hline Group II \& Group III & \multicolumn{5}{|c|}{$\mathbf{P}<0.001^{*}$} \\
\hline
\end{tabular}

Group I (control group), group II (diabetic group), group III (diabetic rats treated with melatonin), MDA (Malondialdehyde), AOPP (advanced oxidation protein product) PON (paraoxonase), GPx(Glutathione peroxidase). 
Table 2. Comparison between the studied groups as regards initial and final body weights $(\mathrm{g})$ using paired t-test.

\begin{tabular}{|l|l|l|l|}
\hline & $\begin{array}{c}\text { Initial body weight }(\mathbf{g m}) \\
\text { Mean } \pm \text { SD }\end{array}$ & $\begin{array}{c}\text { Final body weight (gm) } \\
\text { Mean } \pm \text { SD }\end{array}$ & P-value \\
\hline Group I (n=10) & $115.0 \pm 13.94$ & $152.000 \pm 18.14$ & $<0.001^{*}$ \\
\hline Group II (n=20) & $115.25 \pm 15.86$ & $100.000 \pm 21.28$ & $<0.001^{*}$ \\
\hline Group III (n=20) & $114.500 \pm 13.47$ & $109.400 \pm 16.49$ & 0.112 \\
\hline
\end{tabular}

Table 3: Comparison between the studied groups as regards initial and final fasting plasma glucose level (mg/dl) using paired t-test.

\begin{tabular}{|l|l|l|l|}
\hline & $\begin{array}{c}\text { Initial fasting plasma } \\
\text { glucose level (mg/d) } \\
\text { Mean } \pm \text { SD }\end{array}$ & $\begin{array}{c}\text { Final fasting plasma } \\
\text { glucose level (mg/dl) } \\
\text { Mean } \pm \text { SD }\end{array}$ & P-value \\
\hline Group I (n=10) & $99.00 \pm 12.86$ & $101.00 \pm 11.74$ & 0.393 \\
\hline Group II (n=20) & $102.55 \pm 14.11$ & $353.00 \pm 42.53$ & $<0.001^{*}$ \\
\hline Group III (n=20) & $100.65 \pm 13.912$ & $328.90 \pm 35.82$ & $<0.001^{*}$ \\
\hline
\end{tabular}

Table 4:Correlation matrix between the studied variables in the diseased diabetic groups $(n=40)$

\begin{tabular}{|c|c|c|c|c|c|c|}
\hline \multicolumn{7}{|c|}{ Correlations } \\
\hline & & $\begin{array}{l}\text { Final } \\
\text { fasting } \\
\text { glucose }\end{array}$ & $\begin{array}{l}\text { Liver } \\
\text { MDA }\end{array}$ & $\begin{array}{l}\text { Pancretic } \\
\text { MDA }\end{array}$ & $\begin{array}{l}\text { Plasma } \\
\text { AOPP }\end{array}$ & $\begin{array}{l}\text { Pancretic } \\
\text { GPx }\end{array}$ \\
\hline \multirow{2}{*}{ Liver MDA } & $\mathbf{r}$ & 0.474 & & & & \\
\hline & P-value & $0.002 *$ & & & & \\
\hline \multirow{2}{*}{ Pancreatic MDA } & $r$ & 0.424 & 0.483 & & & \\
\hline & P-value & $0.006^{*}$ & $0.002 *$ & & & \\
\hline \multirow{2}{*}{ Plasma AOPP } & $\mathbf{r}$ & 0.267 & 0.488 & 0.365 & & \\
\hline & P-value & 0.096 & $0.001^{*}$ & $0.020 *$ & & \\
\hline \multirow{2}{*}{ Pancreatic GPx } & $\mathbf{r}$ & -0.583 & -0.314 & -0.497 & -0.347 & \\
\hline & P-value & $0.000^{*}$ & $0.048^{*}$ & $0.001 *$ & $0.007 *$ & \\
\hline \multirow{2}{*}{ PON1 activity } & $\mathbf{r}$ & -0.235 & -0.570 & -0.631 & -0.444 & 0.256 \\
\hline & P-value & 0.145 & $0.000 *$ & $0.000 *$ & $0.004 *$ & 0.094 \\
\hline
\end{tabular}




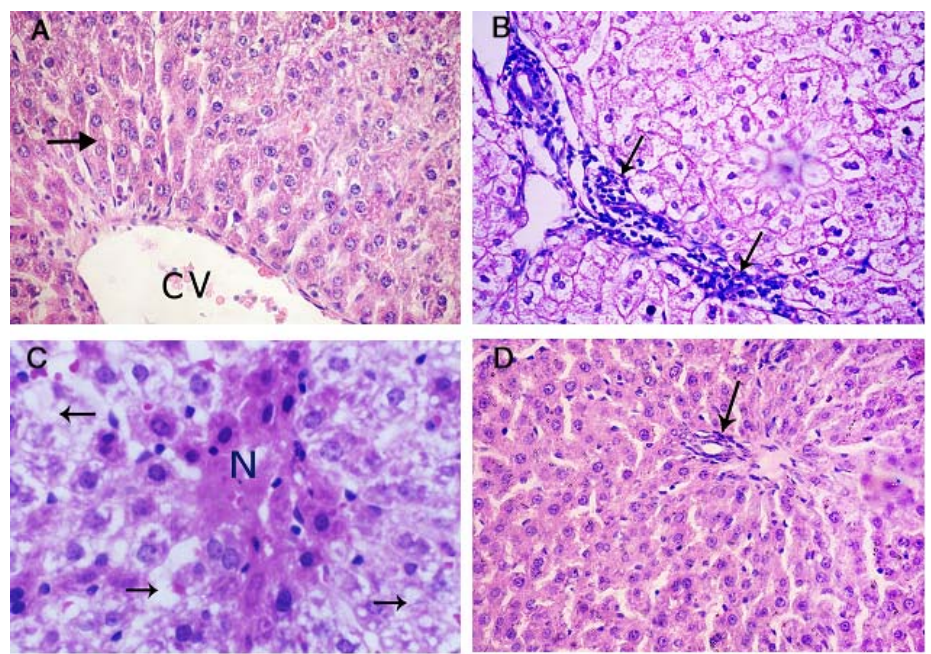

Fig. 1. Light microscopical photomicrograph of liver tissue of control group (A) showing the normal hepatocytes with rounded nuclei forming hepatic cell cords $(\rightarrow)$ radiating from the central vein $(\mathrm{CV})$, liver tissue of diabetic rat $(B)$ showing the hypertrophied and vacuolated hepatic cells and the heavy cellular infiltration $(\rightarrow)$ and (C) shows small areas of focal necrosis and vacuolated hepatocytes. (D) shows liver tissue of diabetic rat treated with melatonin showing the apparently normal hepatic cells with few inflammatory cells around a blood vessel $(\rightarrow)$. (H \&E. Mag. $x$ 400).

\section{DISCUSSION}

ROS have emerged as important molecules in the pathogenesis of diabetic vascular complication. In the present study it was observed that the diabetic rats lose much weight than control rats or diabetic rats treated with melatonin and such result came in accordance with that reported by Vural et $\boldsymbol{a l}^{(21)}$,and Guven et al ${ }^{(2)}$.

There was, also, a significant increase in plasma glucose level in diabetic rats and diabetic rats treated with melatonin compared with control rats with no significant difference between diabetic rats and diabetic rats treated with melatonin indicating that melatonin treatment did not significantly affect plasma glucose levels and did not prevent the development of hyperglycaemia in the STZ-induced diabetic rats and that finding came in accordance with the results of other researchers ${ }^{(2,21)}$. In contrast, Shima et $\boldsymbol{a l}^{\mathbf{2 2})}$ reported that melatonin suppressed hyperglycemia caused by intracerebroventricular injection of 2-deoxy-D-glucose in rats. They reported that melatonin injection suppressed blood glucose levels possibly through a brain site. Maitra et $\boldsymbol{a l}^{(23)}$ stated that melatonin may decrease blood glucose levels through its role on catecholaminergic responses.

The present work demonstrated that MDA levels were significantly higher in both pancreatic and liver homogenates of untreated diabetic rats 
compared with either control rats or melatonin treated diabetic rats. These results came in agreement with those reported by Nishigaki et $\boldsymbol{a l}^{(24)}$ and Higuchi et $\boldsymbol{a l}^{(\mathbf{2 5 )}}$ who stated that lipid peroxidation products increase in naturally and chemically-induced diabetes. Akerblom et $\boldsymbol{a l}^{(\mathbf{2 6})}$ added that this increase in lipid peroxidation is due to elevated production of ROS. It has been shown that cytotoxic actions of STZ on $\beta$-cells are mediated by ROS. STZ enter cells and caused alkylation of DNA. The resulting damage induces activation of polyADP-ribosylation, which leads to depletion of $\beta$ cellular NAD and ATP. Enhanced ATP dephosphorylation supplies a substrate for xanthine oxidase that causes excessive formation of superoxide radicals. Consequently, hydrogen peroxide and hydroxyl radicals are, also, generated $^{(27)}$. Thus, in the present study elevated pancreatic tissue levels of MDA may be caused by STZ, which increases oxidative activity.

Moreover, the lipid content of cell membranes seems to be disrupted by diabetes as proved by increased non-enzymatic glycation, lipid peroxidation and cholesterol/ phospholipid ratio $^{(28)}$. Increased glycation of collagen and plasma proteins in diabetes may stimulate the oxidation of lipids, which in turn may stimulate auto-oxidative reactions of sugars enhancing damage to both lipids and proteins in the circulation and continuing the cycle of oxidative stress $^{(29)}$

In the current study, melatonin treatment was successful in reducing pancreatic and liver MDA levels in STZ-diabetic rats which came in accordance with other studies ${ }^{(\mathbf{3 0 , 3 1})}$. Melatonin eliminates oxygen free radicals, such as hydroxyl radicals, singlet oxygen, hydrogen peroxide, peroxyl radicals and hypochlorous acid, through its direct scavenging action $^{(32)}$. Finally, it was reported that the protective effects of melatonin against $\beta$-cell damage may be related to the interference with DNA damage and polyADP-ribosylation ${ }^{(\mathbf{1 2})}$.

AOPPs have begun to attract the attention of various investigators. AOPPs levels correlated with concentrations of di-tyrosine and advanced glycation end products as indices of oxidant-mediated protein damage $^{(33)}$.

In the present study, it was found that AOPP was significantly higher in plasma of untreated diabetic rats compared with either control rats or those of melatonin treated diabetic rats. These results came in agreement with those of Kalousova et $\boldsymbol{a l}^{(33)}$. Witko-Sarsat et $\boldsymbol{a l}^{(7)}$ reported increased levels of AOPP in hemodialyzed patients without differences between diabetics and non-diabetics, but they did not find any change in AOPP in diabetic patients with normal renal function. In the present study, there was no significant difference in plasma AOPPs level between melatonin treated diabetic group and control group and this finding indicated that melatonin could decrease AOPP formation and this came in accordance with the studies of Eskiocak et $\boldsymbol{a l}^{(34)}$ and Tutunculer et $\boldsymbol{a l}^{(35)}$. Endogenous antioxidant enzymes superoxide dismutase (SOD), catalase (CAT) and glutathione peroxidase (GPx) are responsible for the detoxification of 
deleterious oxygen radicals ${ }^{(36)}$. Piconi et $\boldsymbol{a l}^{(37)}$, mentioned that in diabetes, overproduction of ROS can lead to a decrease in cell antioxidant defenses manifested as a fall in the concentration of a single antioxidant molecule or by a fall in the total antioxidant status. In the present study pancreatic GPx activity was significantly lower in pancreatic homogenates of untreated diabetic rats as compared with control rats and diabetic rats treated with melatonin and this came in agreement with results of Yavuz et $a^{(1)}$ and Wolf et $\boldsymbol{a l}^{(38)}$ who stated that glycation of antioxidant enzymes due to hyperglycemia may be responsible for the reduction in GPx activity. Also, Kashiwagi et $\boldsymbol{a l}^{\left({ }^{(3)}\right)}$ stated that the elevation of glucose concentration reduces the activity of GPx, leading to an accumulation of $\mathrm{H}_{2} \mathrm{O}_{2} . \quad \mathrm{H}_{2} \mathrm{O}_{2}$ catabolism leads to the formation of the superoxide radical anion, while the decrease in plasma glucose concentration causes the activation of the pentose phosphate pathway, inactivation of the sorbitol pathway and consequently, an increase in the NADPH level which is a cofactor required for the resynthesis of GSH which regulates the GPX activity. Furthermore, Andallu et $\boldsymbol{a l}^{\mathbf{( 4 0 )}}$ and Bhatia et al $^{(41)}$ reported that the decreased activities of SOD, CAT and GPx in diabetic rats could be due to increased utilization for scavenging free radicals. In contrast, Kakkar et $\boldsymbol{a} \boldsymbol{I}^{\mathbf{( 4 2 )}}$ stated that the GPx enzyme presented higher activity in pancreas and kidneys of STZ induced diabetic animals and SOD activity was increased in liver, heart and pancreas. These results may be due to differences in the adaptive responses of tissues to the diabetic process. Moreover, there are time-course changes in antioxidant enzymes in the same tissue. In the case of excessive production of ROS, endogenous protective mechanisms may not be sufficient to limit ROS and the damages they cause. To maintain the balance between oxidative and antioxidative process and to avert oxidative stress, an external source of the antioxidant protection system is

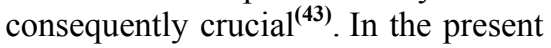
study, melatonin treatment of diabetic rats induced an increase in GPx activity in pancreatic tissues to the levels near to those of control rats and this came in accordance with previous studies ${ }^{(44-46)}$. Moreover, melatonin was shown to stimulate gamma-glutamyl cysteine synthetase (47), the ratelimiting enzyme in GSH synthesis, as well as recycling of GSH in the cell. Thus, melatonin has an important role in maintaining that crucial antioxidant in the liver and increasing the antioxidant capacity of hepatocytes ${ }^{(\mathbf{4 8})}$. In the current study it was found that hepatic GPx activity was not significantly different in the studied groups and this came in accordance with the result of Maritim et $\boldsymbol{a l}^{(\mathbf{4 9 )}}$. As regards plasma PON1 activity, it was significantly lower in diabetic rats compared with the control rats and melatonin treated diabetic rats. Decreased serum PON1 activity might be related to increased lipid peroxide levels and/or glycation of HDL which may increase its turnover and reduce its efficiency. In addition, Abbott et $\boldsymbol{a} \boldsymbol{I}^{(50)}$ and Inoue et $\boldsymbol{a l ^ { ( 5 1 ) }}$ reported that there are some inhibitors against PON1 activity in circulating blood of 
diabetic patients such as glycosylated proteins or disturbance of the interaction of PON with HDL affecting its activity. It was reported previously that PON1 activity was reduced in several situations associated with oxidative stress including, diabetes ${ }^{(\mathbf{5 0})}$, familial hypercholesterolemia and coronary artery disease ${ }^{(17)}$. This led to the hypothesis that PON in some way is involved in the development of atherosclerosis.

Furthermore, it was found that PON may be important in hydrolyzing the toxic lipid esters, e.g. lysophosphatidyl choline produced during the oxidation of LDL, thought to be the initiating stage of atherosclerosis ${ }^{\mathbf{( 5 2 )}}$.

In diabetes, oxidative modification of circulating LDL has been demonstrated. Low HDL-PON activity in diabetes may share in the increase in toxic lipid ester accumulation. It could, therefore, be a factor in the accelerated atherogenesis of diabetes. These findings indicate the intriguing possibility that diabetic atheroma and/or neuropathy may have a partial basis in changes in esterase $\operatorname{activity}^{(53)}$.

In the present study, there was no significant difference as regards PON1 activity between melatonin treated diabetic rats and control rats and this came in accordance with the finding of Topsakal et $\boldsymbol{a l}^{(54)}$ who reported that melatonin may play a role in increasing the reduced PON concentrations by improving the glucose metabolism and/or oxidative stress. As regards the correlations between different studied parameters in the diabetic groups (with or without melatonin injection), plasma glucose level positively correlated with MDA level and this agrees with the study of Jachec et $a^{(55)}$. Komosinska-Vassev et $\boldsymbol{a l}^{(56)}$ found that there was negative correlation between plasma glucose concentration and GPx activity and this came in accordance with the current study.

Lipid peroxidation is one of the characteristic features of chronic diabetes and may bring about protein damage and inactivation of membrane-bound enzymes either through direct attack by free radicals or through chemical modification by its end products such as MDA and thus the current study revealed that there was positive correlation between MDA level and AOPP level and this agrees with that reported by Halliwell $^{(57)}$.

Levy et $\boldsymbol{a l}{ }^{(58)}$ reported that GPx has been known to inactivate lipid peroxidation reactions and thus increased GPx activity results in decreased MDA level and that negative correlation came in accordance with the present study ${ }^{(\mathbf{5 8})}$. Because PON1 inhibits lipid peroxidation in lipoproteins and tissues, this might be another contributing factor for the decreased tissue MDA levels observed in the present study ${ }^{(53)}$ together with the negative correlation found between MDA and PON1 activity which came in accordance with Işık et $\boldsymbol{a l}^{(\mathbf{5 9 )}}$. Also, Genc et $\boldsymbol{a l}^{\left(\mathbf{6 0}^{6}\right)}$ reported that PON inactivation might result from an interaction of oxidized proteins as AOPP with PON active thiol group and assessed the capability of PON to maintain redox status of proteins and this explain the negative correlation 
between PON activity and AOPP level in the present study.

As regards the histological results, they are going with the laboratory data, as in group II, STZinduced diabetic rats, the hepatic cells were markedly hypertrophied and vacuolated with few necrotic areas. Heavy cellular infiltration was, also, noticed in the portal area (Fig.1B and $\mathrm{C})$. These findings are in agreement with those of Lenk et $\boldsymbol{a l}^{(\mathbf{6 1 )}}$ who found that the hepatocytes of STZ-induced diabetic mice showed hypertrophy and autophagic vacuoles, these changes were prevented by insulin administration, indicating that these effects were caused by insulin deficiency and not by STZ toxicity. However, Kume et $\boldsymbol{a l}^{\left({ }^{(62)}\right.}$ stated that many of the hepatic alteration including histopathological and gene expression changes are induced by direct effect of STZ rather than by the secondary effect of the hyperglycemia or hypoinsulinemia. The present results were, also, in agreement with those of Guven et $\boldsymbol{a l}^{(2)}$ who demonstrated hepatic lesions, including disorganized hepatocytes with degenerated cytoplasmic organelles and vacuoles. Moreover, they observed inflammation in the portal areas and focal necrosis in STZinduced diabetic rats.

Melatonin was reported to exhibit a wide variety of biological effects, including antioxidant, antiinflammatory and can prevent the tissue damage and fibrosis ${ }^{(13,14,63)}$. The protective effect of melatonin was demonstrated histologically, as most of the hepatocytes appeared more or less normal and the inflammation was markedly decreased in comparison to the second group. This was in accordance with the result of Guven et $\boldsymbol{a l ^ { ( 2 ) }}$ who mentioned that although melatonin had a preventive effect on STZ-induced diabetic rat liver damage, focal necrosis was permanent in several of the melatonin treated diabetic rats. They added that the administration of melatonin prevented STZ-induced diabetic hepatic dysfunction and inhibited the generation of free radicals and accumulation of neutrophils in the damaged hepatic tissue, and these agents appear to play a cytoprotective role in the liver insulted by STZ induced diabetes. These findings were supported by those of Molpeceres et $\boldsymbol{a l}^{\left(\mathbf{6 4}^{4}\right)}$ who detected liver apoptotic cell death induced by ROS, and the antiapoptotic action provided by melatonin was related to its antioxidant effect. Also, melatonin has free radical-scavenging and antioxidant properties in tissues and preserve both liver function and structure during ischemia and reperfusion injury ${ }^{(65,66)}$ ). Anwer et $\boldsymbol{a l} \boldsymbol{I}^{(67)}$ indicated the role of oxidative stress in the degeneration of pancreatic beta-cells and induction of diabetes in STZ treated rats and that antioxidant treatment is beneficial in diabetic rats, and in diseases associated with oxidative stress.

Finally, evidence is presented that the reversal of established lesions of diabetic liver is possible.

So, in conclusion, melatonin might be used as a supportive therapeutic agent in uncontrolled diabetes to improve the condition of oxidative stress associated with diabetes and to elevate the activity of endogenous antioxidant system. This 
can at least decrease or delay the diabetic complications. Also, chronic administration of melatonin reduced liver injury in STZ-induced diabetic rats and thus it may provide a useful therapeutic option in humans to reduce oxidative stress and the associated hepatic injury in diabetic patients.

\section{REFERENCES}

1. Yavuz O, Cam M, Bukan $N$ and Guven A, and Silan F (2003): Protective effect of melatonin on $\beta$-cell damage in streptozotocininduced diabetes in rats. Acta Histochemica;105(3):261-266.

2. Guven A, Yavuz O, Cam M, Ercan F, Bukan N, Comunoglu C, and Gokce F(2006): Effects of melatonin on streptozotocininduced diabetic liver injury in rats. Acta Histochemica;108:8593.

3. West IC (2000): Radicals and oxidative stress in diabetes. Diabetes Med.;17:171-180.

4. Halliwell B \& Chirico S. (1993): Lipid peroxidation: its mechanism, measurement, and significance. Am. J. Clin. Nutr.; 57:715-725.

5. Kayali R, Telci A, Cakatay U, Karaca C, Akacay T, Sivas A, and Altug T ( 2003): Oxidative protein damage parameters in plasma in chronic experimental diabetes in rats. Eur. J. Med. Res.;(8):307-312.

6. Dalle-Donne I, Rossi R, Giustarini D, Milzani A, and Colombo R. (2003): Protein carbonyl groups as biomarkers of oxidative stress. Clin. Chim. Acta.;329(1-2):23-38.

7. Witko-Sarsat V, Friedlander M, Khoa NT and Blandin C (1998): Advanced oxidation protein products as novel mediators of inflammation and monocyte activation in chronic renal failure. Immunology; 16:2524-2532

8. Mackness B, Hine D, Liu Y, Mastorikou M, and Mackness M (2004): Paraoxonase-1 inhibits oxidised LDL-induced MCP-1 production by endothelial cells. Biochem. Biophys. Res. Commun.;318(3):680-3.

9. Klepac N, Rudes Z, and Klepac $\mathbf{R}$ (2005): Effects of melatonin on plasma oxidative stress in rats with streptozotocin induced diabetes. Biomed. Pharmacother.;60(1):32-5.

10. Cabana VG, Reardon CA, Feng N, Neath S, Lukens J, and Getz GS(2003): Serum paraoxonase: effect of the apolipoprotein composition of HDL and the acute phase response. J. Lipid Res. Apr;44(4):780-92.

11. Mackness B, Durrington PN, and Mackness MI (1998): Human serum paraoxonase. Gen. Pharmacol. ;31(3):329-36.

12. Abdel-Wahab MH, and AbdAllah AR (2000): Possible protective effect of melatonin and/or desferrioxamine against streptozotocin-induced hyperglycaemia in mice. Pharmacol. Res.; 41(5):533-7.

13. Wang H, Wei W, Wang NP, Gui SY, Wu L, Sun WY, and Xu SY (2005): Melatonin ameliorates carbon tetrachloride- 
induced hepatic fibrogenesis in rats via inhibition of oxidative stress. Life Sci.;77(15):1902-15.

14. Cruz A, Padillo FJ, Torres E, Navarrete CM, MuñozCastañeda JR, Caballero FJ, Briceño J, Marchal T, Túnez I, Montilla P, Pera C, and Muntané J (2005): Melatonin prevents experimental liver cirrhosis induced by thioacetamide in rats. J. Pineal Res.;39(2):143-50.

15. Montilla PL, Vargas JF, Túnez IF, Muñoz de Agueda MC, Valdelvira ME, and Cabrera ES (1998): Oxidative stress in diabetic rats induced by streptozotocin: protective effects of melatonin. J. Pineal Res.; 25(2):94-100.

16. Witko-Sarsat V, Friedlander $\mathrm{M}$, Capeillère-Blandin $\mathrm{C}$, Nguyen-Khoa $T$, Nguyen AT, Zingraff J, Jungers $P$, and Descamps-Latscha B (1996): Advanced oxidation protein products as a novel marker of oxidative stress in uremia. Kidney Int.;49(5):1304-13

17. Mackness MI, Harty D, Bhatnagar D, Winocour PH, Arrol S, Ishola M, and Durrington PN (1991): Serum paraoxonase activity in familial hypercholesterolaemia and insulin-dependent diabetes mellitus. Atherosclerosis.; 86(23):193-9.

18. Flohe L \& Gunzler WA (1984): Assays for glutathione peroxidase. Methods Enzymol.; 105:114-121.

19. Lowry OH, Rosebrough NJ, Farr AL, and Randall RJ
(1951): Protein measurement with the folin phenol reagent. J. Biol. Chem.; 193;265-75.

20. Bancroft,J.D. and Cook,H.C. (1994): Manual of histological techniques and their diagnostic application. Churchill, Livingstone Edinburg, London, New York, Tokyo

21. Vural H, Sabuncu T, Arslan SO, and Aksoy N (2001): Melatonin inhibits lipid peroxidation and stimulates the antioxidant status of diabetic rats. J. Pineal Res. ;31(3):193-8

22. Shima T, Chun SJ and Niijima A (1997): Melatonin suppresses hyperglycemia caused by intracerebroventricular injection of 2-deoxy-D-glucose in rats. Neurosci. Lett.;226:119-122.

23. Maitra SK, Dey M, Dutta S and Bhattacharya $S \quad$ (2000): Influences of graded dose of melatonin on the levels of blood glucose and adrenal catecholamines in male roseringed parakeets (Psittacula krameri) under different photoperiods. Arch. Physiol. Biochem.;108:444-450.

24. Nishigaki I, Hagihara M, Tsunekawa H, Maseki M, and Yagi K (1981): Lipid peroxide levels of serum lipoprotein fraction of diabetic patients. Biochem. Med.;25:373-378.

25. Higuchi Y (1982): Lipid peroxides and alpha-tocopherol in rat streptozotocin-induced diabetes mellitus. Acta Med. Okayama;36:165-175.

26. Akerblom HK, Vaarala O, Hyoty $H$ and Ilonen $J$ (2002): Environmental factors in the 
etiology of type I diabetes. Am. J. Med. Genet.;115:18-29.

27. Szkudelski T. The mechanism of alloxan and streptozotocin action in B cells of the rat pancreas. Physiol Res. 2001;50(6):537-46.

28. Watala $C$ and Winocour PD (1992): The relationship of chemical modification of membrane proteins and lipoproteins to reduced membrane fluidity of erythrocytes from diabetic subjects. Eur. J. Clin. Chem. Clin. Biochem.;30:513519.

29. Baynes JW (1991): Role of oxidative stress in development of complications in diabetes. Diabetes.;40:405-412

30. Gorgun FM, Ozturk Z, Gumustas MK and Kokogu E (2002): Melatonin administration affects plasma total sialic acid and lipid peroxidation levels in streptozotocin induced diabetic rats. J. Toxicol. Environ. Health A.;65: 695-700.

31. Baydas G, Canatan $H$ and Turkoglu A (2002): Comparative analysis of the protective effects of melatonin and vitamin $\mathrm{E}$ on streptozotocin-induced diabetes mellitus. J. Pineal Res.; 32:225230

32. Reiter RJ, Tan DX, Osuna C and Gitto $E$ (2000): Actions of melatonin in the reduction of oxidative stress. J. Biom. Sci.; 7:444-458.

33. Kalousova M, Skrha $J$ and Zima T (2002): Advanced glycation endproducts and advanced oxidation protein products in patients with diabetes mellitus. Physiol Res.;51:597604.

34. Eskiocak S, Tutunculer F, Basaran UN and Taskiran A (2006): The effect of melatonin on protein oxidation and nitric oxide in the brain tissue of hypoxic neonatal rats. Brain Dev.;10:1-6.

35. Tutunculer F, Eskiocak S, Basaran UN and Ekuklu G (2005): The protective effect of melatonin in experimental hypoxic brain damage. Pediatr. Int.;47:434-439.

36. Del Maestro RF (1980): An approach to free radicals in medicine and biology. Acta Physiologica Scandinavica.; 492:153-168.

37. Piconi L, Quagliara $L$ and Ceriello A (2003): Oxidative stress in diabetes. Clin. Chem. Lab. Med.;41:1144-1149

38. Wolf SP (1994): Ferrous ion oxidation in presence of ferric ion indicator xylenol orange for measurement of hydroperoxides. Meth. Enzymol.;233:182-189.

39. Kashiwagi A, Asahina T, Ikebuchi $M$ and Tanaka $Y$ (1994): Abnormal glutathione metabolism and increased cytotoxicity caused by $\mathrm{H}_{2} \mathrm{O}_{2}$ in human umbilical vein HDL endothelial cells cultured in high glucose medium. Diabetologia; 32:264-269.

40. Andallu B and Varadacharyulu NC (2003): Antioxidant role of mulberry (Morus Indica L.) leaves in streptozotocin diabetic rats. Clinica Chimica Acta;338:310 
41. Bhatia S, ShuklaR, Madhu SV and Ganbhir KJ (2003): Antioxidant status, lipid peroxidation and nitric oxide end products in patients of type II diabetes mellitus with nephropathy. Clin. Biochem.; 36:557-562.

42. Kakkar R, Mantha SV, Kalra J and Prasad K (1996): Time course study of oxidative stress in aorta and heart of diabetic rat. Clin. Sci.;91:441-448.

43. Rosen $P$, Nawroth PP and King G (2001): The role of oxidative stress in the onset and progression of diabetes and its complication. Diabetes Metab. Res. Rev.;17:189-212.

44. Sailaja Devi MM, Suresh Y and Das UN (2000): Preservation of the antioxidant status in chemically-induced diabetes mellitus by melatonin. J. Pineal Res.;29:108-115.

45. Barlow-Walden LR, Reiter RJ, Abe $M$ and Pablos $M$ (1995): Melatonin stimulates brain glutathione peroxidase activity. Neurochem. Int.;26:497-452.

46. Sener G, Tosun O, Sehirli AO and Kacmaz A (2003): Melatonin and $\mathrm{N}$-acetylcysteine have beneficial effects during hepatic ischemia and reperfusion. Life Sci.;72:2707-2718.

47. Urata $Y$, Honma $S$ and Goto $S$ (1999): Melatonin induces gamma-glutyml cysteine synthetase mediated by activator protein-1 in human vascular endothelial cells. Free Radic. Biol. and Medic.;27:838-847.

48. Rodriguez C, Mayo JC, Sainz RM and Antolin I (2004):
Regulation of antioxidant enzymes: a significant role for melatonin. J. Pineal Res.;36:1-9.

49. Maritim AC, Moore BH, Sanders RA and Watkins III JB (1999): Effects of melatonin on oxidative stress in streptozotosininduced diabetic rats. Int. J. Toxicol.;18:161-166.

50. Abbott CA, Mackness MI, Kumar $S$ and Boulton AJ (1995): Serum paraoxonase activity, concentration, and phenotype distribution in diabetes mellitus and its relationship to serum lipids and lipoproteins. Arterioscler. Thromb. Vasc. Biol.;1511:1812- 1818.

51. Inoue M, Suehiro T, Nakamura $T$ and Ikeda $Y$ (2000): Serum arylesterase/ diazoxonase activity and genetic polymorphism in patients with type II diabetes. Metabolism; 49:1400-1405.

52. Patel BN, Mackness MI, Harty DW and Arrol S (1990): Serum esterase activities and hyperlipidemia in the streptozotocin-diabetic rat. Biochim. Biophys. Acta; 1035:113- 116.

53. Rodrigo L, Hernandez AF, Lopez-Caballero JJ and Gil F (2001): Immunohistochemical evidence for the expression and induction of paraoxonase in rat liver, kidney, lung and brain tissue. Implications for its physiological role. Chem. Biol. Interact.;137:123-137.

54. Topsakal C, Kilic N, Ozveren F and Akdemir I (2003): Effects of prostaglandin E1, melatonin, and oxytetracycline on lipid peroxidation, antioxidant defense 
system, paraoxonase (PON1) activities, and homocysteine levels in animal model of spinal cord injury. Spine;28 (15):16431652

55. Jachec W, Tomasik A, Tarnawski $R$ and Chwalinska $E$ (2002): Evidence of oxidative stress in renal cortex of diabetic rats: favourable effect of vitamin E. Scand. J. Clin. Lab. Invest.;62 (1): $81-88$

56. Komosinska-Vassev $K$, Olczyk $K$, Olczyk $P$ and WinszSzczotka K (2005): Effects of metabolic control and vascular complications on indices of oxidative stress in type II diabetic patients. Diabetes Res. \& Clin. Prac.;68:207-216.

57. Halliwell B (2000): Lipid peroxidation, antioxidants and cardiovascular disease: how should we move forward? Cardiovasc. Res.; 47:410-448.

58. Levy U, Zaltzber H, Ben-Amotz $A$ and Kanter $Y$ (1999): $\beta$ carotene affects antioxidant status in non-insulin dependent diabetes mellitus. Pathphysiology; 6:157161.

59. Ișık SR, Yolaçan $H$ and Ișık MR (2005): Serum Malonyldialdehyde and Parao-xonase Levels in Chronic Obstructive Pulmonary Disease. Turkish Respiratory Journal;6 (1):019021.

60. Genc H, Kayali R, Öncül $M$ and Uzun $H$ (2007): Protein oxidation markers in normal pregnancy and in pregnant woman with diabetes: A possible relationship with paraoxonase activity. Clin. Chem. Lab. Med.;45: S1-S473.

61. Lenk SE, Bhat D, Blakeney W, and Dunn Jr WA. (1992): Effects of streptozotocin-induced diabetes on rough endoplasmic reticulum and lysosomes of rat liver. Am. J. Physiol.;263:E85662.

62. Kume E, Aruga C, Takahashi K, Miwa S, Dekura E, Itoh M, Ishizuka $\mathbf{Y}$, Fujimura $\mathbf{H}$, Toriumi W, and Doi K.(2005): Morphological and gene expression analysis in mouse primary cultured hepatocytes exposed to streptozotocin. Exp. Toxicol. Pathol.;56(4-5):245-53.

63. Tahan V, Ozaras R, Canbakan B, Uzun H, Aydin S, Yildirim B, Aytekin H, Ozbay G, Mert A, and Senturk H. (2004): Melatonin reduces dimethylnitrosamine-induced liver fibrosis in rats. J. Pineal. Res.;37(2):78-84.

64. Molpeceres V, Mauriz JL, García-Mediavilla MV, González P, Barrio JP, González-Gallego J (2007): Melatonin is able to reduce the apoptotic liver changes induced by aging via inhibition of the intrinsic pathway of apoptosis. J. Gerontol. A Biol. Sci. Med. Sci.; 62(7):687-95.

65. Kaçmaz A, User EY, Sehirli AO, Tilki M, Ozkan S, and Sener G (2005): Protective effect of melatonin against ischemia/reperfusion-induced oxidative remote organ injury in the rat. Surg. Today;35(9):744-50

66. Zhang WH, Li JY, and Zhou Y. (2006): Melatonin abates liver 
ischemia/reperfusion injury by improving the balance between nitric oxide and endothelin. Hepatobiliary Pancreat. Dis. Int. ;5(4):574-9

67. Anwer T, Sharma M, Pillai KK, Haque SE, Alam MM, and
Zaman MS. (2007): Protective effect of bezafibrate on streptozotocin-induced oxidative stress and toxicity in rats. Toxicology 5;229(1-2):165-72.

\section{تأثير الميلاتونين على بعض متغيرات الإجهاد التأكسدى في مرض البوال السكرى المفتعل بواسطة الإستربتوزتوسين في الجرذان في الجنان}

$$
\begin{aligned}
& \text { منال البطش* و فتحي الفسخاني*و عبد الرازق شتا***و صنوت قاسم* }
\end{aligned}
$$

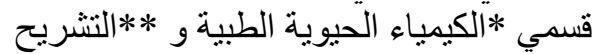

$$
\begin{aligned}
& \text { كلية الطب، جامعة طنطا }
\end{aligned}
$$

يصاحب مرض البو ال السكرى العديد من المضاعفات مثل تصلب الثر ايين و مضاعاعفات

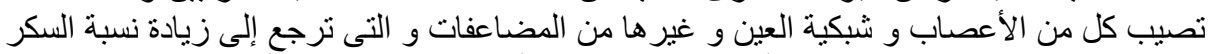

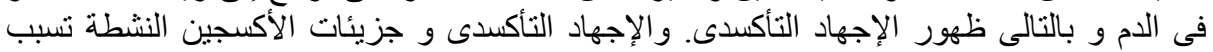

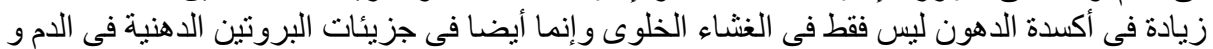

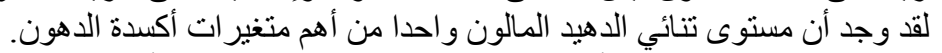

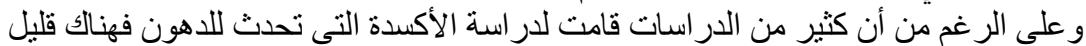

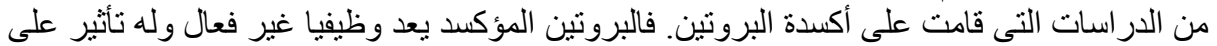

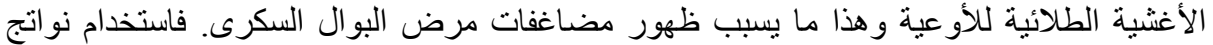

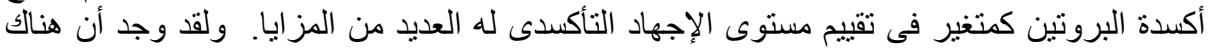

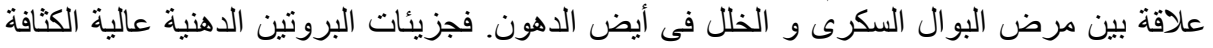

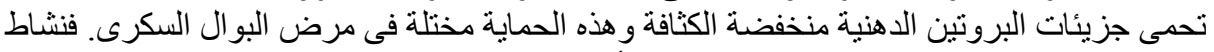

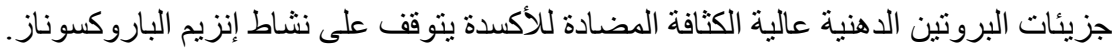

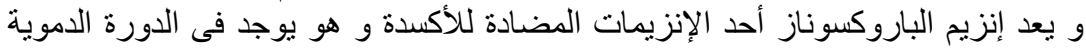

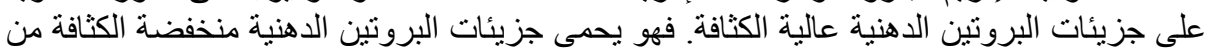

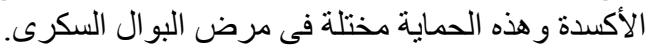

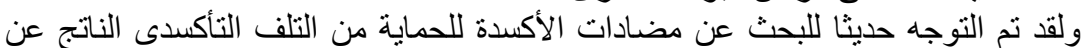

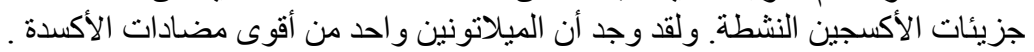

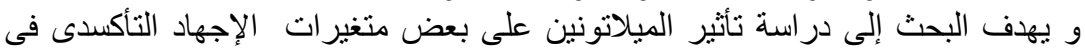

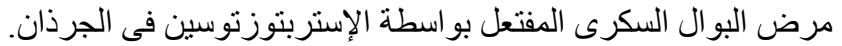

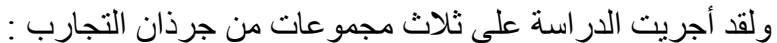

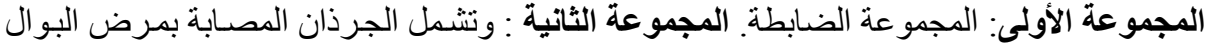

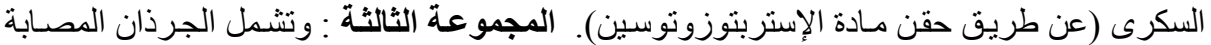
بمرض السكر ويعطى الميلاتونين. 


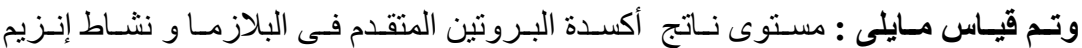

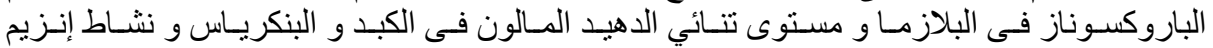

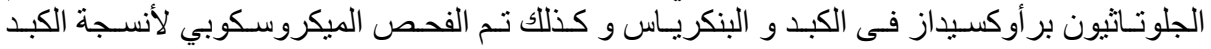

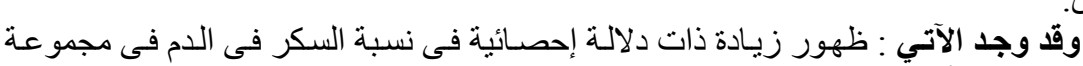

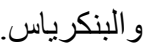

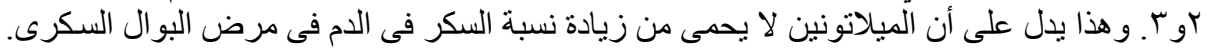

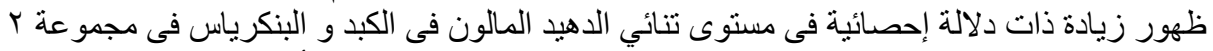

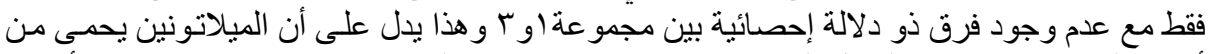

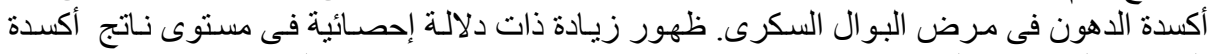

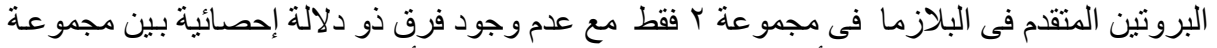

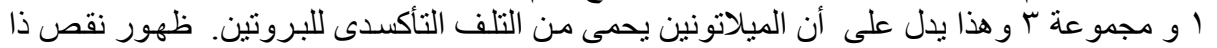

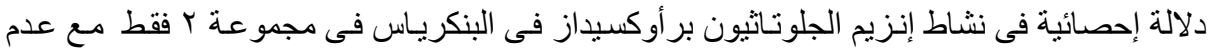

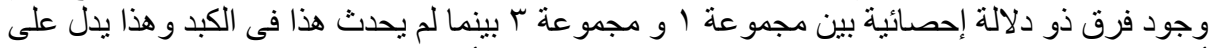

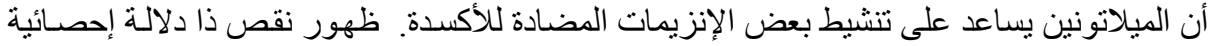

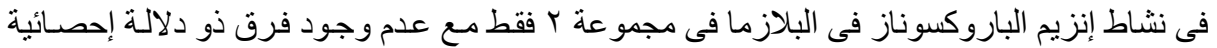

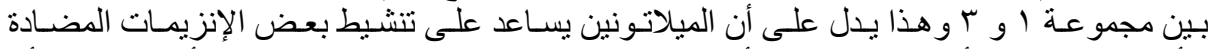

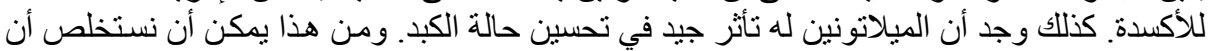

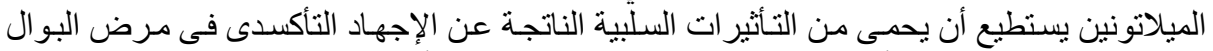

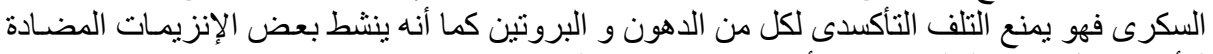
للأكسدة مثل إنزيم الجلوتاثيون برأوكسيداز و إنزيم الباروكسوناز 